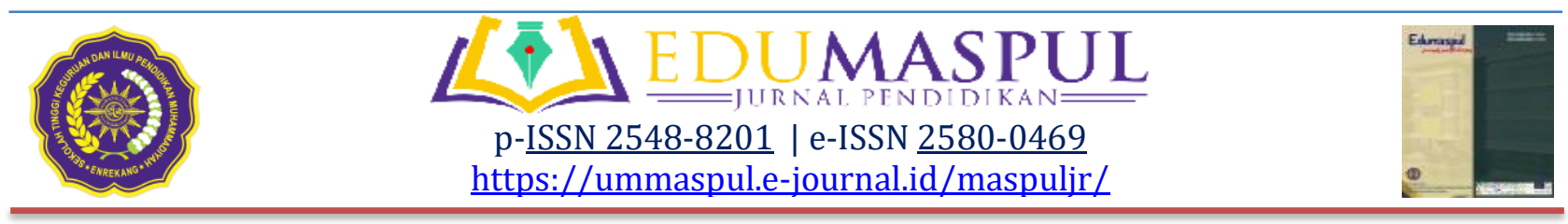

\title{
Reposition of Historical Pesantren, Madrasah and Integrated Islamic School
}

\author{
Hardianto \\ UPT SDN 108 Pinrang, Indonesia \\ $\triangle$ Corresponding email: antohardi001@gmail.com
}

\begin{abstract}
Received: 13-07-2019
Accepted: 29-09-2019

Published: 07-10-2019

Abstract. The aim of this study is describing history and development Islamic boarding schools, madrasa and integrated Islamic school. This research is descriptive-analytic literature research. Research concludes that Islam can be developing and be accepted by Indonesian society through existence an institution that pioneered by the scholars and character education that has spirit religion, development institution education experience install it recede in his journey. Proven by existence effort positive for developing institution Islamic education and shade Ministry of Education and Culture. Since the madrasa was developed together with the emergence of the Islamic reform movement in Indonesia, the madrasa curriculum has always been done the renovation. Initially, the madrasa curriculum only consisted of religious knowledge than experience innovation corresponding with demands the times. Effort massive do by the Ministry of Religion in developing Islamic education institutions. so as Ministry Education and Culture give away opportunity for Integrated Islamic School for designing curriculum education for meet National Education Standards.
\end{abstract}

Keywords: Boarding school, Madrasah, and Integrated Islamic School

Abstrak. Tujuan dari penelitian ini adalah menggambarkan sejarah dan perkembangan pondok pesantren, madrasah, dan Sekolah Islam terpadu. Penelitian ini adalah penelitian literatur deskriptif analitik. Penelitian ini menyimpulkan bahwa Islam dapat berkembang dan diterima oleh masyarakat Indonesia melalui keberadaan lembaga yang dipelopori oleh para cendekiawan dan tokoh pendidikan yang beragama roh, pengalaman pendidikan lembaga pembangunan itu surut dalam perjalanannya. Terbukti dengan adanya upaya positif untuk mengembangkan institusi pendidikan Islam dan menaungi Kementerian Pendidikan dan Kebudayaan. Karena madrasah dikembangkan bersama dengan munculnya gerakan reformasi Islam di Indonesia, kurikulum madrasah selalu melakukan renovasi. Awalnya, kurikulum madrasah hanya terdiri dari pengetahuan agama daripada pengalaman inovasi yang sesuai dengan tuntutan zaman. Upaya besar-besaran dilakukan oleh Kementerian Agama dalam mengembangkan lembaga pendidikan Islam. sehingga Kementerian Pendidikan dan Kebudayaan memberikan kesempatan bagi Sekolah Islam Terpadu untuk merancang kurikulum pendidikan untuk memenuhi Standar Pendidikan Nasional.

Kata kunci: Pesantren, Madrasah, dan Sekolah Islam Terpadu 


\section{INTRODUCTION}

Studying the history of Islamic Education is very important. Especially candidates and educators or Islamic thinkers. By studying the history of Islamic Education, it can be known because of the progress of Islam, because of both the way of upbringing and its teachings and the cause of the decline of Islam, because it is wrong in its methods and teachings. By knowing the history of Islamic education, it can also be understood because of the brightness of the teachings and teachings of Islam and because of complete darkness.

If known in the history of the causes of the progress of Islam, surely we will try the causes - causes of progress. And if it is known the causes of its decline, we will certainly avoid the causes of its decline. By studying the history of Islamic education, we can make a brilliant history in the education that we seek for future generations (Mahmud Yunus, 1990).

Seeing the urgency of the history of Islamic education, from the very beginning of the development of Islam to the present, it is so complex to take understanding. One of the factors of Islam can develop widely is thanks to the services of scholars and government support in developing Islam through an educational institution.

Islamic education views families, communities, and places of worship or educational institutions outside of schools are the main base formation character (Hardianto, 2017). Education for new secular goals arose around the middle of the 19th century with practical reasons and objectives to support commercial interests. However, in the Netherlands alone there are a number of individuals who are aspiring particularly those whose liberal views and adheres to politic etic who saw education as a means to promote the welfare of the Indonesian people spiritual-material it-self. Some even did not hesitate to educate the Indonesian people to achieve political maturity and finally political independence.

Another unexpected consequence was the emergence of thirst and awareness of going to school among the Indonesians who were incarnated in the form of private schools, private schools labeled by the Dutch as "Wilde Scholen", "wild schools". Among them are Taman Siswa based on national principles and Muhammadiyah based on Islam. The Dutch government was unsuccessful in blocking the growth of this "wild school" that soon after private schools exceeded the number of Government schools (S. Nasution, 1983: 153). Scope study boarding school covers the history and development, madrasa history and development, and history integrated Islamic school and its development.

\section{METHOD}

This type of research is library research by analyzing descriptions on some reference. The approach used normative theological approach, historical, juridical, and pedagogical. Time research do since 2018. Researcher start is holding up review literature in Makassar City. The author uses a content analysis model, this study is an in-depth discussion of the content of written information or printed in mass media. Research to literature history Islamic boarding schools, madrasas, and integrated Islamic school. Observation results early to be ingredients consideration appropriateness next for to be ingredients research.

Studies library to research dominated by non- field data collection at once covers the object under study and data used to talk about it, as a primary object at once 
secondary. In obtaining this data, researchers analyzed literature main that is book history institution education and development, and as stretch support in the form of thought Islamic education, books issue Director General of Islamic Religious Education Ministry of Religion of the Republic of Indonesia, guidelines research library.

Data sources obtained from library belongs to institution government (city library), library institution private, library campus and library general belongs to personally. Secondary data sources are additional data in the form of writing, books and other forms of documents that have relations with the object of research, such as photographs, texts and important documents about integrated Islamic school. Data in the form of writing or books about Islamic boarding schools, madrasas, and integrated Islamic schools and other documents serve as reinforcement of findings. Collection of library data does with system open and closed system. System opens the meaning researcher could in a manner directly choose books that are meant while in a closed system taking book do by a librarian (Nyoman Kutha Ratna, 2016).

The instruments used by researchers are writing guidelines. researcher on school the basis of integrated Islam add data through related documents such as documentation photo. Object research or formal object of text, discourse. The formal object in question is language, writing, sign and the medium of the goat used data processing and analysis techniques are carried out starting from data reduction, data presentation, and conclusion drawing. Testing the validity of the data using the data credibility test. Primary data sources are data obtained directly from the object of research. While secondary data sources are additional data in the form of writing, books and other forms of documents relating to the object under study. Processing techniques and data analysis are carried out in several stages, namely data reduction, data presentation, processing and data analysis and testing the validity of the data, and conclusions (Sugiyono, 2017).

\section{Participants}

\section{History of Islamic Boarding Schools}

The birth of a pesantren is a religious response from society. with religious leaders, they carry out a building from within a certain framework or ethos. In this step, there was an effort to make Islam an ethos in people's lives, religious, cultural, economic, social and so on. Following this, success in the formation of what Gus Dur called the 'subculture' was a separate tradition, which was different from the others.

When Hadratusy Syaikh Hasyim Asy'ari and his companions carried out reforms, Islam grew as a social framework, which departed from a framework that was of the nature of jurisprudence (legal jurisprudence), meaning-making Islam a social institution. Since then, Islamic boarding schools are no longer the place of teaching religious sciences that are 'psychic' and have gained more mystical experience, but fiqh sciences and tools (Arabic) have begun to become a major concern. Entering the twentieth century, the Shari'ah factor became very decisive, although at the same time there was also a realization that Islam included faith, worship, morals and other fields. The books that are learned more involve the Shari'ah and the science of tools. (Ayun Darun Setiadi and Education Science Development Team FIP-UPI, 2009: 439)

The existence of pesantren itself has polarization in its education system, 
namely, there are traditional systems (Salafi) and modern systems. Various forms of transfer of knowledge occur in various ways, such as the recitation of classical books after the prayers changed by the method of wetonan, bandongan, sorogan, recitation of the Qur'an bi alGhaib and bi-nnadhar, pengajian akbar, pengajian kiletan (kitab kuning salafy), bahsul masail, deliberation, memorization, classical lectures (madrasi), kuliyah and others. For salafi pesantren in general only teach the science of Islam, from various classical books in Arabic (yellow books) by scholars. The purpose of education is directed at forming a personal figure who knows the rules, pious and practices the knowledge (amil) of morality and tafaqquh fi al-din. The personal profile to be realized is the profile of the Kiai (anre gurutta, tuan guru, or buya). (Ayun Darun Setiadi and FIP-UPI Educational Science Development Team, 2009: 4 40)

Historically the oldest Islamic Education Institution in Indonesia is Islamic boarding schools. Apart from the influence of the Hindu-Buddhist or Arabic, boarding a product of interaction and acculturation of Islam with local culture in the context of the original culture. Islamic boarding schools were still in the form of the simple salaf, and non-classical.

The existence of Islamic boarding schools in the Dutch colonial period was suppressed, could not flourish, could not stand up strong, even underestimated. Islamic boarding schools received close supervision through various ordinances imposed by the Netherlands. The role of the pesantren at this time was limited to the practices of worship, $d a$ 'wah, social and education, while in the political field it abstained because the Dutch prevented any efforts towards the political movement. Hajj pilgrims who leave or go home are supervised, especially those who return from Mecca and establish boarding schools. Nevertheless, in subsequent developments, the pesantren participated in the nationalist movement by fighting against the invaders. The involvement of pesantren is deeper in the problem (Abd. Rachman Assegaf, 2003: 2 85).

Discrimination in education services is somewhat inherited from Dutch colonialism which emphasizes the existence of dualism in education, emphasizing very sharp differences. This dualism system became the dominant feature in the education system during colonial rule. There are different schools for various racial and social groups. The education system is divided into two distinct categories, namely the Dutch school and Indigenous schools, each of which has a curriculum, introductory language, different supervision and selffinancing. Schools that were established by the Dutch colonial government, each other did not have any connection at all and even tended to be separated (Mukhtar, Smasu, Rusmini, 2002: 116).

The founder of the first Islamic boarding school on the island of Java was Maulana Malik Ibrahim (d. 1419), who said that the first Islamic boarding school in Indonesia ranged in 1359 (?). and according to some historical writers, Sunan Raden Rahmat or sunan Ampel actually coached the first Islamic boarding school in East Java. (Marwan Saridjo, 2011: 30)

In general, Islamic boarding schools recognize five important scholars who are assumed to be very influential. They are encyclopedic and multi-disciplinary figures, Nawawi al-Bantani (w.1897), specialist Hadith of Mahfuz Tremas or atTirmisi (w.1919), who are usually nicknamed al-Muhaddis and al-Musnid, the most charismatic spiritualist Khalil Bankalan (w.1924), KHR Asnawi Kudus 
(1861-1959), a traveling cleric who was directly involved in the preaching of bi almaqam wa al-hal through rhetorical and effective language skills, and $\mathrm{KH}$ Hasyim As'yari (1871-1947), the movement's kyai, inspiration for nationalism in the pesantren world (Abdurrahman Mas'ud, 2006) .

\section{Development of Islamic Boarding Schools}

Pesantren is identical to a military academy (cloister) in the sense that they participate in the process of learning experience to be in a perfect preoccupation. Islamic boarding schools consist of a kiai as a leader and santri. The pesantren community has played an important role in Sufi development in the country. XIX Dutch scholar, Berg, reported that moral, moral, and Sufism aspects were the most important parts taught. In addition, in general, the influential pesantren offered the teachings and practices of the tarekat for santri who did not settle in the cottage aka santri kalong. Usually, this last activity is handled by a famous Sufi teacher and is followed by hundreds or thousands of students who are quite old.

Santri means students who have full dedication to the boarding school, possibly derived from the word sashtri, a word from Sanskrit which means a scholar who has the expertise of the scriptures. The word santri means broad and narrow. In a narrow sense means students who study in boarding schools. In a broad sense, it refers to members of the Javanese community who hold fast to the teachings of Islam. It can be seen that santri is not limited to someone who has spent so much time in boarding schools, but who is a member of the Muslim Javanese community and tends to identify himself as a santri. Namely, those who pay attention to religious principles which are the most important part of their life perspective. Thus, says students here ideological content.

As a special characteristic of Islamic boarding schools is the content of the curriculum which is focused on the science of religion, eg Arabic syntax, Islamic law, Islamic jurisprudence system, Arabic ufology, Islamic law, Sufism, date and rhetoric (Hasbullah, 1995: 27).

There are traditional learning methods in Islamic boarding schools, namely learning methods that are organized according to habits that have long been used or the original learning methods of pesantren (rogan, bandongan or wetonan, deliberation, muhafadzah, demonstration, rihlah ilmiyah, muhawarah or muhadatsah, mudzakarah or bahtsul bahtsul, and riyadhah. There are also methods that are new (tajdid). the learning method is new is the method of learning the result of the renewal of the boarding by introducing methods developed in modern society. to modernize by developing alternative forms Not only the aspects of curriculum, management, activities or teaching systems are developed, but pesantren have integrated madrasas into pesantren, in fact, not a few of the existing private madrassas have been established in boarding schools.

In general the purpose of fostering and developing Islamic boarding schools is to Increase and help in order to foster and dynamize Islamic boarding schools throughout Indonesia, Establish boarding schools in the chain to the entire national education system, both formal and nonformal education, fostering citizens so that Muslim personalities are in accordance with the teachings of Islam and instilling that religious feeling in all aspects of life and making it useful for religion, society 
and the state (Zakiah Dradjat et al., 2004: 28).

Islamic boarding schools as educational institutions are non-formal and out of school education. Meanwhile, the pesantren as the education organizer then founded the school. Management and implementation of school and outside school education can be done in an integrated manner. However, what needs to be realized is that the integration in the pesantren is more because of the school students as well as students in other schools held by the pesantren (Abdul Munir Mulkhan, 2002: 182).

Conceptualization boarding schools formal education agency lines and outside the school in the top will put government must be responsible for boarding school life in the form of the education budget. However, on the other hand, such a concept would bury the pesantren as an independent educational institution. The ability of students to their needs for independent living needs to be developed by the government.

\section{MADRASA}

Madrasa History

Madrasas as educational institutions in the form of formal education have been known since the beginning of the 11 th century or 12 th century, or the $5-6$ th century $H$., namely since the existence of Nidzamiyah Madrasas established in Baghdad by Nizam al-Mulk, a vizier from the Saljuk Dynasty. The establishment of the madrasa has enriched educational institutions in the Islamic community Abdul Rahman Shaleh, 2006: 11)

Historically, the existence of madrassas in Indonesia has existed since the beginning of the 20th century. Why madrasas in the Dutch colonial period, not before. There are two analyzes. First, because several times the proposal of the Volksraad (People's Council) for Islamic studies to be included as subjects in public universities was always rejected by the Dutch. This led to an initiative to establish a school model outside of Dutch policy that gave more content to Islamic religious studies but was different from the composition of Islamic education material in the existing pesantren. Secondly, the madrasa emerged because of the demands of renewal of Islamic education internally, both in terms of methods and contents. At that time there was a need for LPI other than Islamic boarding schools which were able to provide general knowledge in a classical way so as not to be left behind by the progress achieved by the school formed by the Dutch.

Mahmud Yunus explained that Islamic education was held in surau with unclassified classes and also did not use benches, tables, and blackboards, only sitting cross-legged. Then start to change little by little until now. Islamic education which was first class and used benches, tables and blackboards, was an Adabiah school in Padang. The first Madrasas in Minangkabau, even throughout Indonesia, because according to our investigation there are no madrassas which were first established from the Adabiyah Madrasah, which was founded by the Almighty. Sheikh Abdullah Ahmad in 1909. Adabiah lived as a madrasa (religious school) until 1914 (Mappanganro, 1996: 13).

\section{Development of Madrasa}

Madrasa come from Arabic. The basic word "darasa" means learning, madrasah means temple to learn. Madrasas also mean schools or groups, philosophers, thinkers or certain investigators who hold 
the same method or thinking. The use of the word madrasa, now in Indonesia refers to a form of Islamic education institution and is an integrated part of Indonesia's national education system (Mappanganro, 1996: 7).

Conceptually madrasas cover all types of schools including "non-Islamic" (general) schools. But it should be noted, never before and almost no school labeled "non-Islamic" would like to recognize itself as "madrasa" especially "Islamic school", because, in practice, the designation of madrasas specifically intended for schooling practices that are managed, implemented and intended for Muslims. The issue of the use of the notion of madrasa as "a public school that is characterized by Islam" is also not appropriate, because it results in the emergence of "a sense of language" which leads to the narrowing of the meaning of "Islam" as "the religion of Islam". Furthermore, the concept of madrasah has been reduced by the scope of science as limited to the concept of science that is in harmony with religion. The concept of "religion" is rooted in an anthological understanding. Religion in the sense of occupying space and time/existence concretely as a doctrine of religious teachings (Superior Services (Muliana, 2005: 220).

In the Decree of the Minister of Religion concerning the curriculum of educational institutions, each with No. 74 of 1976, No. 74 of 1976, No. 75 of 1976, No. 3 of 1983 and No. 48 of 1978, explained.

1) Madrasah Ibtidaiyah is an educational institution that provides low education and teaching and makes Islamic religious subjects a basic subject of at least $30 \%$ in addition to general subjects.
2) Madrasah Tsanawiyah is an educational institution that provides junior secondary education and teaching.

3) Madrasah Aliyah is an educational institution that provides upper secondary education and teaching.

4) Early Islamic Madrasah is an educational institution that provides education and teaching of Islamic Religion, which functions primarily to fulfill the desires of parents so that their children get more Islamic Education. Early Madrasah consists of three levels:

a) Diniyah Awaliyah Madrasah (beginner level), with a four-year study period from class I to IV with 18 lessons a week.

b) Diniyah Wustha Madrasah (junior secondary level), with a two-year study period from classes I and II with 18 hours of study in a week.

c) Diniyah 'Ulya Madrasah (upper secondary level), with a two-year study period of classes I and II with 18 hours of study in a week ( Zakiyah Dradjat et al : 2004: 104).

Since the madrasa was developed together with the emergence of the Islamic reform movement in Indonesia, the madrasa curriculum continues to change. Initially, the madrasa curriculum only consisted of religious knowledge. This form of the madrasa is known as madrasah diniyah which has existed since the first centuries of Islamic history in the Middle East. General science, just extensively studied in the madrasa, especially since 1945 independence, the position of general science has continued to strengthen as the development of the lives of Muslims and Indonesian society continues. This madrasa is now referred to as a public school characterized by religion where religion is only part of the curriculum of this institution. 
The first form of intervention by the Indonesian government to bring the "santri" poles closer to the general secular school education system is the implementation of compulsory education Madrasas (MWB). After the pack Munawir Sjadzali appointed Minister of Religion in 1983, from his observation on the quality of madrasah and patterns his observation madrasah pattern SKB has turned into a 'public school' and instructed the DirectorGeneral of Institutions Guidance to consider establishment or implementation one model madrasah curriculum 70\% religion and 30 general. Which is called the Special Madrasah Aliyah Program, such as MAN PK in Makassar.

In 1994, the development of the madrasa experienced a very important period, during which year the Ministry of Religion, a place where the madrasa took shelter imposed a new curriculum, hereinafter referred to as the "1994 curriculum". The curriculum requires that madrasas fully implement the curriculum of public schools under the auspices of the Ministry of Education and Culture. This is certainly very different from the 1995 curriculum, where the madrasa curriculum contains $70 \%$ of general subjects and $30 \%$ of Islamic subjects (Suwito, 2008: 292)

At the end of 1995-1996, In this case, the Directorate General of Institutional Development establishes several MAN Models. In response to Law No. 20 of 2003 concerning the National Education system in article 50, namely the existence of an International Standard School. So the Directorate General of Islamic Education did not want to lose and participated in organizing International Standard Madrasas in a number of regions, such as madrasah al Azhar al-Syarif. and madrasah Insan Cendekia.
Madrasas that were initially expected to be able to bring up religious experts and Islamic leaders began to be doubted whether this condition could still be done. As we know that there are three traditional functions of the madrasa, namely; transfer of Islamic knowledge, maintenance of Islamic tradition, and as a media for the reproduction of ulama. (Marwan Saridjo, 2011)

To implement the policies mentioned above, and to leverage the strengths and opportunities and overcome weaknesses and challenges, Directorate-General for Development of Institutional Islam or in this case the Directorate of Madrasah and Islamic Education Public Schools implements the development strategy of madrassas called enlightenment madrasah (Abdul Rahman Saleh, 2006).

Enhancement Access, Quality, and Madrasa Relevance

In line with direction Policy national and the Ministry of Religion for doing Required 12 years of study in a manner evenly distributed, then RA and Madrasah strategies are prioritized on enhancement access and quality means and infrastructure education, students, educators, and power education, institutions, and curriculum madrasa learning. Strategy set for reach $\mathrm{p}$ that is among others: access madrasa education in the form of, quality means infrastructure madrasa education, quality madrasa students, quality educator and power madrasa education, guarantee quality (quality assurance) institutional madrasah, quality curriculum madrasa learning (RI Ministry of Religion , 2018).

\section{INTEGRATED ISLAMIC SCHOOL}


The government and observers of the world of education are positive on activities shades religious, which was held in schools below shade Office of Education (or Ministry of Education and Culture ), for example, the use of Muslim and Muslim clothing, the lively prayer in congregation, tadarrus and tilawah al-Qur'an. The development of religious values-based schools, such as the Integrated Islamic School. Integrated Islamic School, started from the level of kindergarten, elementary school, school middle class first and school middle class Up.

One of them for example, Makassar Integrated Islamic Elementary School (SDIT) Ar-Rahmah Makassar City as one of the educational institutions, is also responsible for education which leads to the planting of the character of students from an early age. Ar-Rahmah Makassar with all its facilities and infrastructure and educators with their competencies have implemented the integration of science and rejected the dichotomy of science in Islamic education.

The Integrated Islamic School was established by bringing a new concept in the world of education, namely the concept of "integrated". The integrated term is not just a combination of the National Education curriculum with the foundation curriculum, but also the integration between intellectual, emotional, and spiritual intelligence. It also includes efforts to develop children's creativity and analytical skills through the learning pattern of Student Active Learning (SAL) so that it is expected to create multiple intelligences in students.

The concept of education is contained in student learning activities, both intra and extra-curricular which are combined in their entirety. The concept gave birth to one an educational institution called SDIT Ar-Rahmah. SDIT Ar Rahmah is a school that implements the integration of Islamic values in all its learning. Islam is taught not to be in a separate lesson but in all aspects of life. Starting from dressing, talking and behaving, students are expected to refer to the teachings brought by the Prophet Muhammad.

This school was born from the concerns of the management of the Ar Rahmah Foundation (Inggrit Burhan, 2003). The result of a joint decision to agree on the formation of the "Iqro Tamalenrea Foundation" was a combination of the management of the Ar-Rahmah Foundation and the Al-Ikhlas Mosque foundation (SDIT Ar-Rahmah Makassar, 2015).

Vision, Mission, and Features of SDIT ArRahmah Makassar.

Vision

Become a leading SDIT in Eastern Indonesia

\section{Mission}

Foster and realize the generation of Rabbani, carry out Integrative and creative Islamic education, become a reference and study center for the development of quality and professional education, realizing the pre-professionalism of Islamic da'wah in the field of education.

\section{Feature}

Professional management of school management by implementing (Total Quality Management ); teacher capacity and competence are standardized according to the field of teaching, a highly competitive education curriculum based on SAL excellence and integration of Islamic values by using multi-media teaching, Achievement of 80 scores, $100 \%$ UN graduate quality 
with specific abilities: able to speak English, understand Arabic, be able to use a computer, memorize 1-2 juz (juz 30-29), complete infrastructure and school facilities with a comfortable, healthy, beautiful, spacious and religious school environment, Adequate financial resources from self-help parents, potential donors and school businesses that are halal and thoyyib, and form a " character building " (SDIT Ar-Rahmah Makassar, 2011).

\section{Reposition of Islamic Education Institutions}

A school is a social institution, whose form and development depend on other institutions in the community. School functions to educate young people who will become citizens on tomorrow are determined by several factors (Hasan Langgulung, 1985).

School is a system which consists entirely of input, process, and output/outcome components. In this case, what is said to be input is something that influences the ongoing process, the process is changing something into something else, while the output is something that is the result of the process. Islam as a view of life encompasses all fields of human activity, therefore it has cognitive, affective and motoric aspects. In terms of cognitive Islam is taught as a science because it contains factual elements. In advancing Islamic education in schools, the Ministry of Religion has formulated the characteristics of the Islamic Religious Education curriculum as follows:

1) Must highlight religion and morals taken from the Qur'an and Hadith

2) Pay attention to the development of a comprehensive holistic personal aspect of students, body, mind, and spirit.

3) Paying attention to the equilibrium between person and society, the world and society, body, mind, and spirit.

4) Paying attention to the vast element of art.

5) Noting the differences in culture found in the community. (Team of Director General Islamic Institutional Development, 2001 ) .

The education system in integrated Islamic elementary schools is designed to encourage students to become accustomed to practicing the characteristics of Islamic personality. To develop basic science and technology capabilities and teaching materials skills refer to the curriculum of the Ministry of National Education, while teaching materials for introducing Islamic law (diniyah) refer to the curriculum of the Ministry of Religion.

Integrated Islamic School patterned full-day school. This means that learning time lasts from morning to evening. Formation of integrated students formally carried out in the school environment and under the responsibility of the teacher. While out of school (evening - night), integrated coaching of students is done at home and in the environment with parents and the community.

The provision of science and technology and skills is carried out through an integrated approach that relies more on a formal - structural approach, an approach that is carried out through formal face-toface in official learning hours. Another approach that can be applied is a formalnonstructural approach, namely, the process of absorbing Islamic values in each the subjects given to students include 
dealing with subjects whose content is contrary to Islam.

Based on the educational problems faced by looking at the child development phase and empirical reality in the form of the high attention of Muslims especially in the genres of secondary education, a draft of integrated Islamic school education for the middle level (SMPIT and SMUIT) was drafted (Muhammad Ismail Yusanto et al., 2004).

Islamic boarding schools, schools, and madrasah institutions in Indonesia have their own characteristics, which can be distinguished from each other, especially in terms of the portion of their religious learning materials and affiliations with relevant departments. Islamic boarding schools, for example, contain religious material predominantly, whereas madrasas prior to 1975 included 70\% religious material and $30 \%$ general material, and after the 3 Ministerial Decree of 1975 , the composition was reversed to $30 \%$ religious material and $70 \%$ general material. Nonetheless, specifically for this madrasa, in 1986 a pilot project madrasah was held which followed the composition of $70 \%$ religious material and $30 \%$ general material, as was the case before 1975 . The number of these pilot schools was limited to a few regions. The existence of the Special Program State Madrasah Aliyah (MAN PK) is a concrete example of the implementation of the policy.

\section{CONCLUSION}

The oldest Islamic Education Institution in Indonesia is Islamic boarding schools. Pesantren is a product of interaction and acculturation of Islam with local culture in the context of the original culture (Indigenous). Islamic boarding schools are able to deliver the Indonesian people to achieve independence and educate the nation's life after independence.

The existence of madrassas in Indonesia has been around since the beginning of the 20th century. madrasa emerged because of demands for renewal of Islamic education internally, both in terms of methods and contents.

Pesantren and madrasas take a strategic position in the intellectual life of the nation, including there in integrated Islamic school. Basic science and technology development capabilities and skills in institution Islamic education, teaching materials referring to Ministry National Education curriculum, teaching materials was the introduction of Islamic (tsaqafah (diniyah) refers to the curriculum of the Ministry of Religion. Integrated Islamic School patterned fullday school synergized curriculum Ministry of Education on the basis of religion. The main factor in developing Islamic education institutions is a quality educator without ignoring means and infrastructure.

\section{References}

[1] Assegaf, Abd. Rachman. Internasionalisasi Pendidikan. Yogyakarta: Gama Media, 2003.

[2] Dradjat, Zakiah, dkk. Ilmu Pendidikan Agama Islam. Cet. V; Jakarta: Bumi Aksara, 2004

[3] Yayasan Iqra Tamalanre. Grand Desain SDIT Ar-Rahmah Makassar, tahun 2011.

[4] Hasbullah. Sejarah Pendidikan Islam di Indonesia. Cet. II; Jakarta: PT. Raja Grafindo, 1996.

[5] Hardianto. Strategic Instructional on Character Education. Journal of Education and Human Development September 2017, Vol. 6, No. 3, pp. 118129

[6] Langgulung, Hasan. Pendidikan dan Peradaban Islam. Cet. III; Jakarta: PT. Maha Grafindo, 1985. 
[7] Mappanganro. Eksistensi Madrasah dalam Sistem Pendidikan nasional. Ujung Pandang: CV. Berkah Utami, 1996.

[8] Mas'ud, Abdurrahman. Dari Haramain ke Nusantara: Jejak Intelektual Arsitek Pesantren. Cet. I; Jakarta: Kencana, 2006.

[9] Muliana, Jasa Ungguh. Pendidikan Islam Integratif. Cet. I; Yogyakarta: Pustaka Pelajar, 2005.

[10] Mukhtar, Samsu, Rusmini. Pendidikan Anak Bangsa. Cet. I; Jakarta: PT. Nimas Multima, 2002.

[11] Mulkhan, Abdul Munir. Nalar Spiritual Pendidikan. Cet. I; Yogyakarta: PT. Tiara Wacana Yogya, 2002.

[12] Nasution, S. Sejarah Pendidikan Indonesia. Cet. I; Bandung: Jemmars, 1983.

[13] Ratna, Nyoman Kutha. Metodologi Penelitian. Cet. II; Yogyakarta: Pustaka Pelajar, 2016.

[14] Shaleh, Abdul Rahman. Madrasah \& Pendidikan Anak Bangsa Visi, Misi \& Aksi. Jakarta: PT. Raja Grafindo Persada, 2006.

[15] Setiadi, Ayun Darun, dan Tim Pengembang Ilmu Pendidikan FIP-UPI. Ilmu dan Aplikasi Pendidikan dengan tema Pendidikan Pesantren. Cet. III;
Bandung: PT. Imperial Bhakti Utama, 2009.

[16] Suwito, Sejarah Sosial Pendidikan Islam. Cet. II; Jakarta: Kencana, 2008.

[17] Sugiyono, Metode Penelitian Pendidikan. Cet. XXV; Bandung: Alfabeta, 2017.

[18] Saridjo, Marwan. Pendidikan Islam dari Masa ke Masa. Cet. II;Bogor: Al-manar Press, 2011.

[19] Tim DirjenPembinaan Kelembagaan Agama Islam. Kendali Mutu Pendidikan Agama Islam. Cet. I; t. , 2001.

[20] Tobroni. Prophetic Character Transformation for Development of Peace Culture in the School in Indonesia. Journal of Education and Practice, Vol.5, No.32, 2014

[21] Yunus, Mahmud. Sejarah Pendidikan Islam. Cet. VI; Jakarta: PT. Hidakarya Agung, 1990.

[22] Yusanto, Muhammad Ismail, dkk. Menggagas Pendidikan Islami. Cet. I; Bogor: Al-Azhar Press, 2004.

[23] Burhan, Inggrit. Dokumen Notaris SK. Menteri Kehakiman dan HAM RI No. C512.HT.03.01-Th.2001 Tanggal 20 Nopember 2001 (SK. Kepala Badan Pertanahan Nasional No. SK 3-XA-2003 Tanggal 27 Februari 2003. 